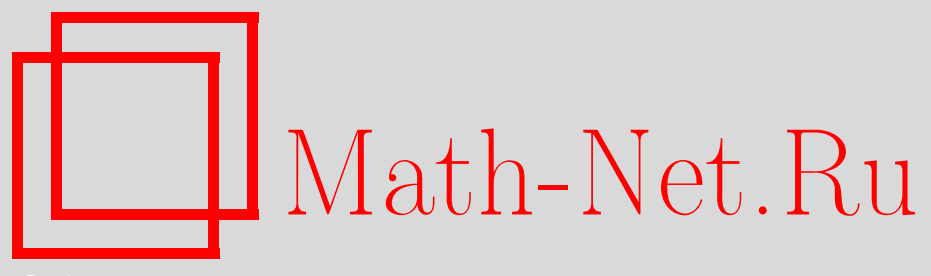

Ю. И. Любич, В. А. Марченко, С. П. Новиков, М. И. Островский, Л. А. Пастур, А. Н. Пличко, М. М. Попов, Е. М. Семёнов, С. Л. Троянский, В. П. Фонф, Е. Я. Хруслов, Михаил Иосифович Кадец (некролог), УМН, 2011, том 66, выпуск 4, 179-180

DOI: https://doi.org/10.4213/rm9433

Использование Общероссийского математического портала Math-Net.Ru подразумевает, что вы прочитали и согласны с пользовательским соглашением http://www.mathnet.ru/rus/agreement

Параметры загрузки:

IP : 54.209 .52 .79

26 апреля 2023 г., 13:05:04

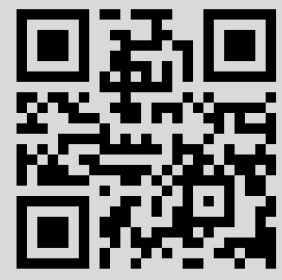




\section{Михаил Иосифович Кадец}

7 марта 2011 г. ушел из жизни Михаил Иосифович Кадец.

Михаил Иосифович родился 30 ноября 1923 г. в Киеве. После окончания средней школы и службы в армии он поступил в 1946 г. на физикоматематический факультет Харьковского государственного университета. Еще будучи студентом, Михаил Иосифович заинтересовался теорией банаховых пространств. В 1948 г. в украинском переводе вышла знаменитая книга Банаха "Théorie des opérations linéaires" (1932). Михаил Иосифович глубоко изучил ее и заинтересовался многими поставленными там проблемами. Эта книга стала для него настольной, а поставленные Банахом проблемы интересовали Михаила Иосифовича на протяжении всей жизни.

После окончания университета он уехал из Харькова в г. Макеевку Донецкой области, где

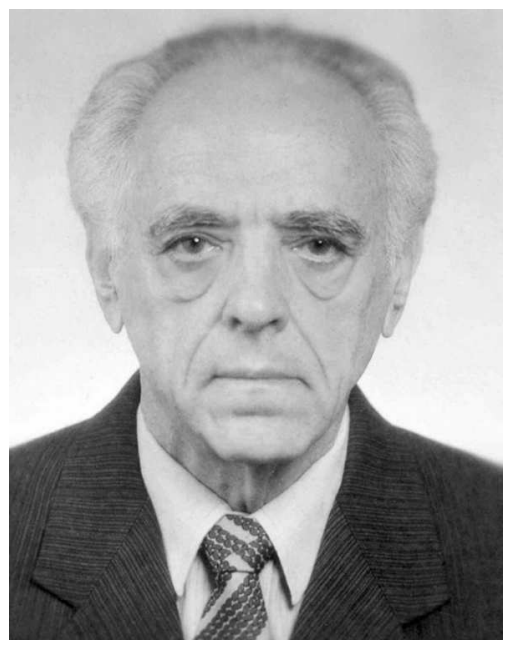
в течение 7 лет работал в НИИ Министерства угольной промышленности и преподавал математику и физику в пожарно-технической школе. В аспирантуре Михаил Иосифович не был и научного руководителя в общепринятом смысле не имел.

В Макеевке Михаил Иосифович получил свои первые существенные научные результаты, по которым в 1955 г. защитил в Харькове кандидатскую диссертацию. В 1957 г. он вернулся в Харьков и с тех пор работал в различных высших технических учебных заведениях города. В 1963 г. Михаил Иосифович защитил докторскую диссертацию. Его работы этого периода были посвящены двум направлениям: топологической классификации банаховых пространств и векторным рядам. Отсюда возникло множество задач, которыми он занимался в дальнейшем.

После 12 лет напряженной работы в первом направлении Михаил Иосифович решил в положительном смысле давно стоявшую проблему Фреше-Банаха о гомеоморфизме всех сепарабельных бесконечномерных банаховых пространств. Этот замечательный результат сразу стал классическим.

Одним из средств, предложенных Михаилом Иосифовичем при решении этой проблемы, является построение эквивалентных норм, удовлетворяющих специальным условиям выпуклости. При этом оказалось, что техника эквивалентных норм эффективна в гораздо более широком круге проблем геометрии банаховых пространств и нелинейного анализа. Михаил Иосифович по праву считается одним из создателей теории эквивалентных перенормировок банаховых пространств, превратившейся в настоящее время в самостоятельную область.

Основные результаты Михаила Иосифовича в теории рядов относятся к бесконечномерным аналогам известной теоремы Штейница о перестановках. Последняя является конечномерным аналогом классической теоремы Римана об условно сходящихся числовых рядах. Для рядов в $L_{p}$ Михаил Иосифович нашел достаточные условия 
на скорость убывания элементов ряда, при которых множество сумм его сходящихся перестановок есть сдвинутое подпространство. Позже Е. М. Никишин и П. А. Корнилов доказали, что эти условия являются необходимыми. Если же не налагать никаких дополнительных условий, то множество сумм может иметь совсем другую структуру. В совместной работе Михаила Иосифовича и К. Возняковского (1989) доказано, что в любом бесконечномерном банаховом пространстве найдется ряд, множество сумм сходящихся перестановок которого состоит из двух точек.

Большое значение для развития теории рядов в банаховых пространствах имеет книга "Series in Banach spaces: conditional and unconditional convergence" (Birkhäuser, 1997), написанная Михаилом Иосифовичем совместно с В. М. Кадецом.

С момента выхода украинского перевода книги Банаха прошло более 60 лет. За это время лицо теории банаховых пространств существенно изменилось, во многом благодаря работам Михаила Иосифовича. Практически все его результаты получили то или иное продолжение, а некоторые из них легли в основу целых направлений современной теории банаховых пространств. Приведем несколько примеров.

Теорема М.И. Кадеца о том, что сепарабельное банахово пространство обладает эквивалентной дифференцируемой по Фреше нормой тогда и только тогда, когда сопряженное пространство сепарабельно, стала одним из основных результатов в теории гладких перенормировок (см. монографию: R. Deville, G. Godefroy, V. Zizler, Smoothness and renormings in Banach spaces, Wiley, 1993).

Оценка Кадеца-Снобара проекционной константы $n$-мерного нормированного пространства и оценка Гурария-Кадеца-Мацаева расстояния Банаха-Мазура между $n$-мерными $l_{p_{1}}$ и $l_{p_{2}}$ представляют собой существенный вклад в теорию конечномерных пространств (см. монографию: N. Tomczak-Jaegermann, Banach-Mazur distances and finite"=dimensional operator ideals, Wiley, 1989).

Теорема Кадеца-Кюрстена о счетности спектра векторнозначной функции, почти периодической на каждом линейном функционале, и теорема Кадеца о максимальном классе банаховых пространств, в которых справедлива теорема Боля-Бора об интеграле от почти периодической функции, - важнейшие результаты теории векторнозначных почти периодических функций.

Фундаментальные результаты М. И. Кадеца и А. Пелчинского о линейно-топологической структуре пространств $L_{p}$ имеют многочисленные приложения не только в теории банаховых пространств, но и в теории функций.

Теорема Кадеца о существовании такого сепарабельного банахова пространства $E$, что каждое сепарабельное пространство со свойством ограниченной аппроксимации изоморфно дополняемому подпространству $E$, является одной из основных в теории универсальных пространств Банаха.

Теорема Кадеца об 1/4 является решением знаменитой проблемы Пэли-Винера о базисности системы экспонент в пространстве $L_{2}$.

Много внимания и сил Михаил Иосифович уделял педагогической работе. Девятнадцать его учеников защитили кандидатские диссертации и семь из них стали докторами наук. М. И. Кадец щедро делился своими математическими идеями с учениками. Харьковская школа Кадеца получила мировую известность. В частности, о ней как об особом явлении в области теории банаховых пространств упоминает А. Пич в своей книге "History of Banach spaces and linear operators" (Birkhäuser, 2007).

В 1991 г. Михаилу Иосифовичу было присвоено звание "Заслуженный деятель науки Украины", а в 2005 г. он стал лауреатом Государственной премии Украины.

Михаил Иосифович был блестящим и одновременно необычайно глубоким математиком, добрым и отзывчивым человеком, остроумным и приятным собеседником. Таким он и останется в нашей памяти.

Ю.И. Любич, В.А. Марченко, С.П. Новиков, М.И. Островский, Л. А. Пастур, А.Н. Пличко, М. М. Попов, Е. М. Семенов, С.Л. Троянский, В.П. Фонф, Е.Я. Хруслов 